\title{
Analyzing Fit in CSR Strategy Research in State-Owned Enterprises: Indonesia Context
}

\author{
Muafi \\ Universitas Pembangunan Nasional "Veteran" Yogykarta (Indonesia) \\ muafi2013@gmail.com
}

Received: October 2015

Accepted: February 2016

\section{Abstract:}

Purpose: We attempted to empirically examine the fitness level of enterprises CSR strategy and its context with contingency and configuration approach. Furthermore, we used 213 CSR managers of state-owned enterprises in Indonesia as samples

Design/methodology/approach: We used the purposive sampling technique to examine the data, also the contingency and configuration approach are measured with regression Euclidean distance.

Findings: The result of the configuration and contingency approach has shown fit between CSR strategy and elements of contingency such as socialization tactic and time orientation. This condition also emerges on proactive CSR strategy and reactive CSR strategy, However, there are limitations of this study: an existence of the influence of the situation and condition when this study takes time; there is a concern on the result of not generalizing population, also the organizational performance only considered the size of organizational performance from non financial measure.

Research limitation: (a) respondents' answers are highly influenced by situation and condition when the study takes time. Although validity and reliability tests has shown the right outcome, there is still a possibility of a bias, (b) state-owned enterprises in Indonesia are represented by CSR manager samples with purposive technique so there is a concern on the result for not 
generalizing population, (c) this research only used primary data through questionnaires. It would be better to combine both primary and secondary data for future researches, (d) organizational performance only considered the size of organizational performance from non financial measure.

Originality/value: There is a methodological contribution in testing the fit of a relationship, both contingency and configuration are superior in terms of research method which used Euclidean distance, and used multivariate fit and bivariate fit linear regression. This research model used systematic approach by testing the fit of a relationship, using deviation from design ideal type for socialization tactic and time orientation or contingency variable that influences organizational performance, hence it could be acknowledged the value of the influence between ideal relationship from CSR strategy, socialization tactic and time orientation.

Keywords: fit, socialization tactic, time orientation, organizational performance

\section{Introduction}

In Indonesia, the Law of Limited Corporation N. 40 Year of 2007 has been used as the basis for Corporate Social Responsibility (CSR) implementation. The objective of CSR in Indonesia is to create a continuous economy development to enhance the life quality for companies and stakeholders. There are several companies in Indonesia that have their own categories for CSR implementation. Several companies are included into obedience, managerial and strategic stage (Suparyono, 2012; Uriarte, 2008). In implementing CSR, several managers are still facing a number of hardships (D'Amat, Henderson \& Florence, 2009), especially in allocating budget and executing the program (In Indonesia it is called Program Kemitraan and Bina Lingkungan - PKBL, Suparyono, 2012).

Besides, several managers have also faced problems in practiting socialization to their new employees who initiate CSR in the field. This is because, almost every year, companies have their own programs to be fitted with society needs in a really wide and heterogeneous scope (Suprapto, 2006). This creates problem for manager in implementing CSR. Therefore, companies need to create a fit between CSR strategy and contingency variables by conducting socialization tactic and time orientation to increase organizational performance.

Socialization tactic is needed by CSR manager for new CSR staff so they can execute studies toward old and new values implemented by their companies (Kreitner \& Kinicki, 2007), and also connected to their job fit (Ashforth, Sluss \& Saks, 2007). The behavior of CSR managers is often time oriented because CSR is made to be succeeding at certain timeframe. Time 
orientation that covers polychronicity and monochronicity has become an important matter for someone to be beneficial to adjust the balance of time (Lindquist \& Scarborough, 2007), which at the end will make better of performance (Love, 2009; Sanderson, 2012; Konig \& Waller, 2010). This research is made to fill the gap of a rare topic which is the importance of socialization tactic, time orientation and CSR strategy on organizational performance in stateowned enterprises in Indonesia.

\section{Literature Review and Hypotheses Formulation}

\subsection{CSR Strategy and Organizational Performance}

New research on CSR has focused on companies to allocate their substantial resources for prosperity of the society. Several researchers suggest the companies to see their CSR budget as an investment rather than an expense (Ali, Rehman, Yilmaz, Nazir \& Ali, 2010a; Ali, Rehman, Ali, Yousaf \& Zia, 2010b), because CSR is a part of organizational business strategy (McElhaney, 2009).

Kemp (2001) discussed the implementation of CSR in developing countries by focusing on the importance of CSR strategy. The reality is when leaders work with their people to craft a CSR strategy for their company; they should at minimum pursue the following course of action (McElhaney, 2009). Therefore, before choosing strategy, company should analyze and diagnose their internal and external environment (SWOT analysis) (Elbana \& Alhwarai, 2012; David, 2009). A chosen strategy should be implemented effectively for CSR program to run well. This will deliver competitive advantage and high organizational performance for the company (Oliver \& Holzinger, 2008; Lee, 2008; Berry \& Rondinelli, 1998; Fang, Huang \& Huang, 2010).

CSR strategy is always related to stakeholders' demands, therefore companies and stakeholders should have a harmonious relationship (Wood, 1991; Fang et al., 2010). Company should use CSR to strengthen their relationship with stakeholders, including customers, investors, government, suppliers and employees. This relationship can also be functioned to minimize the conflict between companies and their stakeholders as well as guaranteeing the loyalty of all stakeholders (Ali et al., 2010b).

Hendriques and Sadorsky (1996) stated that there are several factors that influence a company in implementing strategy and approach to natural environment so it will increase organizational performance, namely: (1) environment pressure, come from internal (shareholders and employees) and external, (2) company's financial position, (3) attitude of face-to-face with the environment, company's attitude in having a long-term environment management plan, (4) company size, and (5) industrial regulations. In the meantime, stakeholders as the source of pressure are divided into four: regulatory stakeholders, 
organizational stakeholders, community stakeholders and the media (Hendriques \& Sadorsky, 1999). In adopting proactive, CSR is characterized by several activities: shared vision, stakeholder management and strategic proactivity. It is expected that companies with proactive CSR will influence their financial performance (Torugsa, O'Donohue \& Hecker, 2012). Fang, et al. (2010), Wartick and Cochran (1985) and Hendriques and Sadorsky (1999) categorize CSR strategy into four, namely: reactive, accommodative, defensive and proactive. In this research, CSR strategy is divided into two typologies, reactive and proactive approach by referring Fang, et al. (2010), Wartick and Cochran (1985) and Hendriques and Sadorsky (1999) as shown in Table 1. A reactive CSR has the same characteristic with Porter's cost reduction strategy or Miles and Snow's defender. Just as known that Porter's cost reduction strategy has similar characteristic with Miles and Snow's defender. On the other hand, innovation strategy has a similar characteristic with prospector strategy (Muafi, 2009; Kumar, Subranian \& Yauger, 1997).

\begin{tabular}{|l|l|}
\hline \multicolumn{1}{|c|}{ Reactive } & \multicolumn{1}{c|}{ Proactive } \\
\hline No support or involvement of top management & $\begin{array}{l}\text { Top management supports and is involved in } \\
\text { environmental issues }\end{array}$ \\
\hline Environmental management is not necessary & $\begin{array}{l}\text { Environmental management is an important business } \\
\text { function }\end{array}$ \\
\hline No environmental reporting & Internal and external reporting \\
\hline No employee environmental training and involvement & $\begin{array}{l}\text { employee environmental training and involvement } \\
\text { encouraged }\end{array}$ \\
\hline $\begin{array}{l}\text { Respond only to certain } \\
\text { Demands }\end{array}$ & $\begin{array}{l}\text { Creating and satisfying needs, taking the role of industry } \\
\text { leader. e.g. Mold new demands for stakeholders and } \\
\text { satisfy them }\end{array}$ \\
\hline $\begin{array}{l}\text { Increasing efficiency and legitimacy through adjusting } \\
\text { internal procedures }\end{array}$ & $\begin{array}{l}\text { Taking action to mold and redefine major stakeholder } \\
\text { demands in the operating environment to conform beliefs } \\
\text { to match with organizational benefits }\end{array}$ \\
\hline
\end{tabular}

Table 1. Typology of CSR Strategy (Hendriques \& Sadorsky, 1999; Fang et al., 2010)

If CSR strategy has been chosen, the next challenge is dealing with the limitation of CSR implementation (D'Amat et al., 2009). Generally, such challenge is related to political issue or on organizational level and often embedded on organizational culture. The complexity in operation has made them to implement CSR strategy effectively. Such company needs to deliver satisfaction for all stakeholders, including new challenge towards organization to use CSR and strategic tool (Ali et al., 2010a). Rahim, Jalaludin and Tajuddin (2011) focus on the CSR components have a significant relationship with consumers' buying behavior. Ali et al. (2010b) underline that the importance of CSR to increase satisfaction and retention for stakeholders and towards company's continuous performance. 
Research result from Aragón-Correa (1998) concludes that company that uses proactive business strategy will use corrective approach and natural environment approach preventively. Research result from Suprapto (2006) concludes that a company will gain a benefit when there is a fit between natural environment policy with business strategy. In a wiser perspective, Aragon-Corea and Rubio-López (2007) concludes that there is relationship between business and society as well as the importance of developing measurement real and eco-sustainability strategy.

It has been proven from several studies that the performance of a company will be influenced from organizational strategy (Taleghani, Delafrouz \& Tonekaboni, 2012; Muafi, 2008, 2009). Heslin and Ochoa (2008) and Arx and Ziegler (2008) also stressed the importance of corporate social responsibility for company's success which is organizational performance (Brammer, Millington \& Rayton, 2007). The researchers of employees behavior and CSR have been advising CSR to build a stronger relationship between company's employees and to achieve a better organizational performance. They also stressed the positive aspect from stakeholders' commitment on organizational performance.

CSR strategy is giving contribution in achieving organization's objectives. This has been proven that financial benefit from CSR strategy can be found in human resources area, reputation, branding and operational cost saving (McElhaney, 2009). McElhaney (2009) has advised that for the future, company should focus, not just in increasing CSR but also in having intelligence and strategically integrating CSR strategy from day to day with business strategy, focusing on the best CSR communication for stakeholders and paying attention to brands from company's CSR to increase organizational performance. Organizational performance in this research used non-financial performance measurement approach, namely: work quality, work satisfaction, organizational capability, organizational adaptability and service quality (Muafi, 2008, 2009; Homburg, Krohmer \& Workman Jr, 1999; Harel \& Tzafrir, 1999; Alleyne, Doherty \& Greenidge, 2005).

\subsection{Contingency and Configuration Approach}

\subsubsection{Contingency Approach}

According to the contingency theory, it is difficult to accept that what works well in one organization may not necessarily run well on other organizations because of different possible strategies, culture, management style, technology or inappropriate work practices. Therefore, universalistic advice is extremely difficult to apply (Armstrong, 2008).

The essence of contingency theory is that an organization must adapt to the organizational structure or other contingencies such as the environment, the size of the organization, and 
the business strategy if the organization wants to obtain a high performance (Edelman, Brush \& Manolova, 2005). It is clear that for any organization operating in a particular environment, it is necessary to adjust to the demands of external and internal environment in which the organization operates. According to the contingency theory, the chosen strategy to deal with certain situations depends on the type of situations faced by the managers themselves. Therefore, a manager must have the ability to identify methods in situations and conditions and at a specific time so as to contribute best in achieving organizational performance. In principle, different situations require different managerial reactions, so managers need to learn specific contingencies that are thought to increase company performance. Some research and studies linking strategy with elements of contingency have been done by some experts (Lukas, Tan \& Hult, 2001; Luo, 1999; Shane \& Kolvereid, 1995; Robertson \& Chetty, 2000; Selto, Renner \& Young, 1995). The result generally concludes that the contingency fit between strategy as a major variable and variable contingency studied had an influence on organizational performance (organizational commitment, job satisfaction, job involvement, services and other organizational performance).

\subsubsection{Configuration Approach}

Configuration theory is putting a holistic approach by looking at the ideal type and explicitly adopt a system that assumes deadlines. HR practices will be more effective if there is a compliance with the corporate strategy and other elements (Twomey \& Harris, 2000; Armstrong, 2008). A successful strategy revolves in combining both of the 'vertical' (external fit) and 'horizontal' (internal fit) aspects in a strategy. This is a combination of the configuration utility in human resource practices that can be mutually complementary and encouraging. A configuration of human resource practices should have a higher level of performance, so the companies that apply this concept will also achieve a high level of conformity with the organization's strategy. Priyono (2004) stated that in a configuration perspective, we are testing the fit concept of the two sides in the strategy - the horizontal fit and vertical fit. Horizontal fit shows the consistency practices of human resources or internal employment system, while vertical fit shows the relationship suitability between strategy, structure, culture and human resource system that will ultimately affect organizational performance. The horizontal fit concept in a configuration perspective is equal to the concept of Human Resources Bundles, in which the concept of HR Bundles would be more appropriate to analyze the relationship of organizational performance, rather than analyzing them individually (Priyono, 2004).

Likewise, as described by Dyer and Reeves (1995), in which they stated that (1) bundles or configurations of human resource activities are very important in improving labor 
productivity than single activity, and (2) bundles can control employee turnover and improve product quality. Therefore $H R$ Bundles must be integrated with other business functions practices or complementary bundles to create a more effective organization. This opinion is supported by Delaney and Husehild (1996), Björkman and Xiucheng (2002) and Luo (1999). Criticism of this approach is the absence of proof that a particular configuration is generally better than the others, although the practice of performance management and competency framework are the two ways that are typically applied to provide an integration between human resource activities (Armstrong, 2008). In general, the contingency fit approach only performs a selection and a partial interaction between variables and fails to consider the 'fit' status holistically or as a whole (multiple) (Choe, 2003; Selto, et al., 1995).

\subsection{Socialization Tactic and CSR Strategy}

New CSR agents are often facing hardship when implementing CSR. They have a problem in adopting value, norm and wanted behavior from managers and organization. Task demand, role demand and private demand needs to be balanced to make CSR implementation fully succeed. Research from Suparyono (2012) shows that before executing CSR program, company needs to do a sort of mapping of budget allocation and CSR program priority to make the process easier. The consideration can be based from the following seven criteria: company reputation, conflict potency, income contribution, man power absorption, business opportunity, region economy growth, and even distribution. These several criteria sometimes need the right decision making. Therefore, socialization tactic and high participation is needed from the employees of CSR agents in the field. This condition will be harder when operation regional scope is much farther from company's central office.

Kreitner and Kinicki (2007) explained that there are three steps of socialization:

- anticipatory socialization,

- encounter, and

- acquisition.

Anticipatory socialization is started before an individual joins an organization. Socialization information is initially coming from various sources. In this stage, all formal and informal informations, be it accurate or inaccurate, help such individual to anticipate organization's facts. Managers can use performance review to make their employees endure their positions in the organization. The second stage, encounter, is started when work contract has been signed. New employees build a set of manual and interpretation to explain and to 
make a working activity in the company to mean something. Many companies use new combination for training and orientation program to socialize their employees in meeting process. Individuals are challenged to solve any sort of conflict between job and other concerns when there are so many problems occurred during CSR implementation. This makes CSR agents often confused and therefore gain a high work stress. Acquisition stage leads to task mastery and conflict solving that starts the final stage of such socialization process. Those with no experience in this third stage will be isolated in organization's social network. Senior executive often plays a direct role in this stage. Baker III and Feldman (1991) has made six socialization tactic typology by summarizing from Van Maanen and Schein (1979) such as following Table 2.

This typology can be connected with organizational strategy shows in Table 3. To make the grouping easier, the left part is abbreviated as ForColSeqFixSerDiv (formal, collective, sequential, fixed, serial, divestiture), and the right is abbreviated as InInRanVarDisIn (informal, individual, random, variable, disjunctive, investiture).

\begin{tabular}{|c|}
\hline $\begin{array}{l}\text { Formal } \\
\text { The degree to which the setting in which the socialization } \\
\text { takes place is segregated from the ongoing work context } \\
\text { and the degree to which an individual newcomer role is } \\
\text { emphazised and made explicit }\end{array}$ \\
\hline $\begin{array}{l}\text { Individual } \\
\text { The degree to which individuals are socialized singly, } \\
\text { analogous to unit modes of production }\end{array}$ \\
\hline $\begin{array}{l}\text { Sequential } \\
\text { The degree to which the transitional processes are } \\
\text { marked by a series of discrete and identifiable stages } \\
\text { through which an individual must pass in order to } \\
\text { achieve a defined role and status within the organization }\end{array}$ \\
\hline $\begin{array}{l}\text { Fixed } \\
\text { The degree to which the recruit is provided with a precise } \\
\text { knowledge of the time it will take him to complete a } \\
\text { given step }\end{array}$ \\
\hline $\begin{array}{l}\text { Serial } \\
\text { The degree to which experienced members groom } \\
\text { newcomers about to assume similar roles in the } \\
\text { organization }\end{array}$ \\
\hline $\begin{array}{l}\text { Investiture } \\
\text { The degree to which the socialization processes ratify } \\
\text { and establish the viability and usefulness of the } \\
\text { characteristics the person already possesses. The degree } \\
\text { to which the socialization processes confirm the incoming }\end{array}$ \\
\hline
\end{tabular}

\section{Informal}

The degree to which there is no sharp differentiation from other organizational members and much of the recruit's learning takes place within the social and task related networks that surround his or her position

\section{Collective}

The degree to which individuals are socialized collectively, analogous to batch or mass production modes of production

\section{Random}

The degree to which the socialization processes are accomplished in one transitional stage

\section{Variable}

The degree to which the recruit is not provided with any advanxe notice of his transition timetable

\section{Disjunctive}

The degree to which a newcomer does not have predecessor available in in whose footsteps he can follow

\section{Divestiture}

The degree to which the socialization processes deny and strip away certain entering characteristics of a recruit. The degree to which the socialization processes dismantle the incoming identity of a newcomer

Table 2. Van Maanen's People Processing Strategies (Baker III \& Feldman, 1991;

Van Maanen \& Schein, 1979) 


\begin{tabular}{|l|l|l|}
\hline Oganizational strategy & Cost reduction & Innovation \\
\hline Individual Response & Conformity & Role Innovation \\
\hline & Formal & Informal \\
& Collective & Individual \\
Socialization Tactics & Sequential & Random \\
& Fixed & Variable \\
& Serial & Investiture \\
\hline
\end{tabular}

Table 3. Linking Socialization Tactics with Oganizational strategy (Baker III \& Feldman, 1991)

Socialization program can be used to understand external challenge from organization and understanding HR policies in socialization that can be used to facilitate strategic achievement (Schuler \& Jackson, 1987; Baker III \& Feldman, 1991). ForColSeqFixSerDiv socialization tactic will fit with embedded characteristic on cost reduction strategy. On the other hand, Ashforth, et al. (2007) stated that institutional socialization and proactive behavior connected with newcomer and their studies. Socialization process, substantially and symbolically, has an influence to newcomer's adaptability. As advised by Saeed, Shamsodon and AhmadReza (2013) that organization should not be just aware and responsive on proactive behavior but also consider institutional interaction and individual socialization tactic. Organization shall give training to insiders and socialization agents in responding positively for such newcomers. This is significant because there is a benefit to achieve organizational performance (Baker III \& Feldman, 1991; Rodopman, 2009), such as work satisfaction, organizational commitment, turnover intention, social integration, task mastery and role clarity (Chen \& Eldridge, 2010).

Research results of Saks, Uggerslev and Fassina (2007) explained that institutionalized socialization tactics were negatively related to role ambiguity, role conflict, and intention to quit and positively related to fit perceptions, job satisfaction, organizational commitment, job performance and a custodial role orientation. This indicates that socialization tactics is negatively related to a negative individual response and vice versa. Results of this researach are supported by Ashforth et al. (2007) explaining that institutionalized socialization tactics have a relationship with proactive behavior for learning new comers. The finding of Gruman, Saks and Zweig (2006) emphasized that there is an independent relationship between organizational tactics, self efficacy, proactive behaviors, and socialization outcomes. This finding is also supported by Jones (1986) and Takeuchi and Takeuchi (2009) which explained that variable outcomes include job satisfaction and organizational commitment. Moreover, Allen (2006) found that socialization tactics enable organizations to actively embed new employees; collective, fixed, and investiture tactics were positively related to on-the-job embeddedness. Results also indicate that on-the-job embeddedness is negatively related to turnover and mediates relationships between some socialization tactics and turnover. This will certainly have an impact on organizational performance. 
H1. In contingency approach, there is more fit relation between CSR strategy (proactivereactive) and socialization tactic (InInRanVarDisIn-ForColSeqFixSerDiv), it will be able to increase the organizational performance

H1a. In contingency approach, there is more fit relation between proactive CSR strategy and InInRanVarDisIn socialization tactic, it will be able to increase the organizational performance.

H1b. In contingency approach, there is more fit relation between reactive CSR strategy and ForColSeqFixSerDiv socialization tactic, it will be able to increase the organizational performance.

\subsection{Time Orientation and CSR Strategy}

Time is an important matter in organizational research (Palmer \& Schoorman, 1999; Sanderson, 2012). Most of the time, time can be managed, kept or thrown away. The understanding on time orientation and how far an individual respond is an important consideration to predict work performance in daily work environment (Sanderson, 2012). Schriber and Gutek (1987), Sanderson (2012) and Love (2009) stated that time orientation is an important dimension of organizational culture. Several important matters, including time orientation are; time boundaries between work and nonwork, sequencing of tasks, punctuality, allocation, awareness, synchronization and coordination, variety versus routine, intraorganizational time boundaries, future orientation, schedules and deadlines, work pace, autonomy of time use, and quality versus speed. This time orientation concept has an important implication in organizational behavior research (Sanderson, 2012), even though research on the relationship between time orientation and one's performance is limited (Kaufman-Scarborough \& Lindquist, 1999).

Love (2009) stated that several researchers nowadays are building time orientation concept through monochronicity and polychronicity concepts. Such concept has a tacit (implied) characteristic and is a dimension that may shape human behavior. Goonetilleke and Luximon (2010) stated that monochronicity and polychronicity is one's ability to do one thing and many things at once, respectively and studied all the time. Characteristics from each monochronicity and polychronicity are grouped by Kaufman-Scarborough (2003) and can be seen in the following Table 4. 
Monochronicity (M)

\begin{tabular}{|l}
\hline Do one thing at a time \\
\hline Concentrate on the job \\
\hline Take time commitments (deadlines, schedules) seriously \\
\hline Are low-context and need information \\
\hline Are committed to the job \\
\hline Adhere religiously to plans \\
\hline $\begin{array}{l}\text { Are concerned about not disturbing others; follow rules of } \\
\text { privacy and consideration }\end{array}$
\end{tabular}

privacy and consideration

Show great respect for private property; seldom borrow or lend

Emphasize promptness

Are accustomed to short-term relationships

\section{Polychronicity (P)}

Do many things at once

Are highly distractable and subject to interruptions

Consider an objective to be achieved, if possible

Are high-context and already have information

Are committed to people and human relationships

Change plans often and easily

Are more concerned with those who are closely related (family, friends, close business associates) than with Privacy

Borrow and lend things often and easily

Base promptness on the relationship

Have strong tendency to build lifetime relationships

Table 4. Contrast characteristics between Monochronicity (M) and Polychronicity (P)

(Kaufman-Scarborough, 2003)

Love (2009) stated that monochronicity and polychronicity concept is a part of organizational culture. Competitive advantage through organizational culture can be built by increasing swiftness in service and productivity productivity (Whipp, Adam \& Sabelis, 2002). Bates (1992), Muafi (2009) and Gomez (2004) stated that organizational strategy has a tight relationship with organizational culture. The fit between organizational culture and organizational strategy will increase organizational performance even more (Kotter \& Heskett, 1992; Hickman \& Silva, 1984). If there is fit between apollo culture and defender strategy, it will increase organizational performance, on the other hand, if there is a fit between athena culture and prospector strategy, it will increase organizational performance (Muafi, 2009; Zwaan, 2006). Apollo culture has an identical characteristic with socialization tactic of ForColSeqFixSerDiv. On the other hand, test on two elements from organizational culture which is polychronicity and speed values can actually influence organizational performance (Onken, 1999).

Relevancy from this research has made companies leaders to be more responsible in implementing organizational culture as a company's resource. Added by Love (2009), several organizations prefer polychronicity structure to increase their competitive advantage where there is a need for manager to consider workplace and employees change. Polychronicity will be significant if it's connected with personality of extraversion, agreeableness and openness to experience. The same thing applies with multitasking ability and polychronicity (Sanderson, 2012). Goonetilleke and Luximon (2010) stated that monochronicity individual is focused on respondents attention in their main tasks and achieving highest performance while polychronicity individual has a higher total performance in a limited time. This indicated that time usage of an individual should consider training and controlling to understand the difference between one another. 
Research results of Love (2009) concluded that when polychronicity of employees is high, his organizational commitment will also be high, and vice versa. The stress level of employees will be higher when they are faced with monochronicity challenges. Companies must have a strategy to improve those kinds of conditions in order to improve job satisfaction, performance, employee's wellbeing, and reduce turnover. Zhang (2013) added that by using a multiple regression polychronicity approach, employees will be positively related to job satisfaction and work engagement and will be negatively related to turnover intention. Research findings of Souitaris and Maestro (2010) explained that polychronicity has a positive effect on company performance in a dynamic unanalyzable environments condition. This effect is partially mediated by decision speed and comprehensiveness. These findings also proved that there is a relationship between polychronicity and organizational strategy in improving organizational performance, which are also supported by McGahan and Mitchell (2003).

H2. In contingency approach, there is more fit relation between CSR strategy (proactivereactive) and time orientation (polychronicity-monochronicity), it will be able to increase the organizational performance.

H2a. In contingency approach, there is more fit relation between proactive CSR strategy and polychronicity time orientation, it will be able to increase the organizational performance.

$H 2 b$. In contingency approach, there is more fit relation between reactive CSR strategy and monochronicity time orientation, it will be able to increase the organizational performance.

H3. In configuration approach, there is more fit between CSR strategy (proactive-reactive) and variable of socialization tactic (InInRanVarDisIn-ForColSeqFixSerDiv) and time orientation (polychronicity-monochronicity), it will be able to increase the organizational performance.

H3.a. In configuration approach, there is more fit between proactive CSR strategy and variable of InInRanVarDisIn socialization tactic and polychronicity time orientation, it will be able to increase the organizational performance.

H3.b. In configuration approach, there is more fit between reactive CSR strategy and variable of ForColSeqFixSerDiv socialization tactic and monochronicity time orientation, it will be able to increase the organizational performance.

This literature has been used to develop the conceptual framework for this study as shown in research model (see Figure 1). 


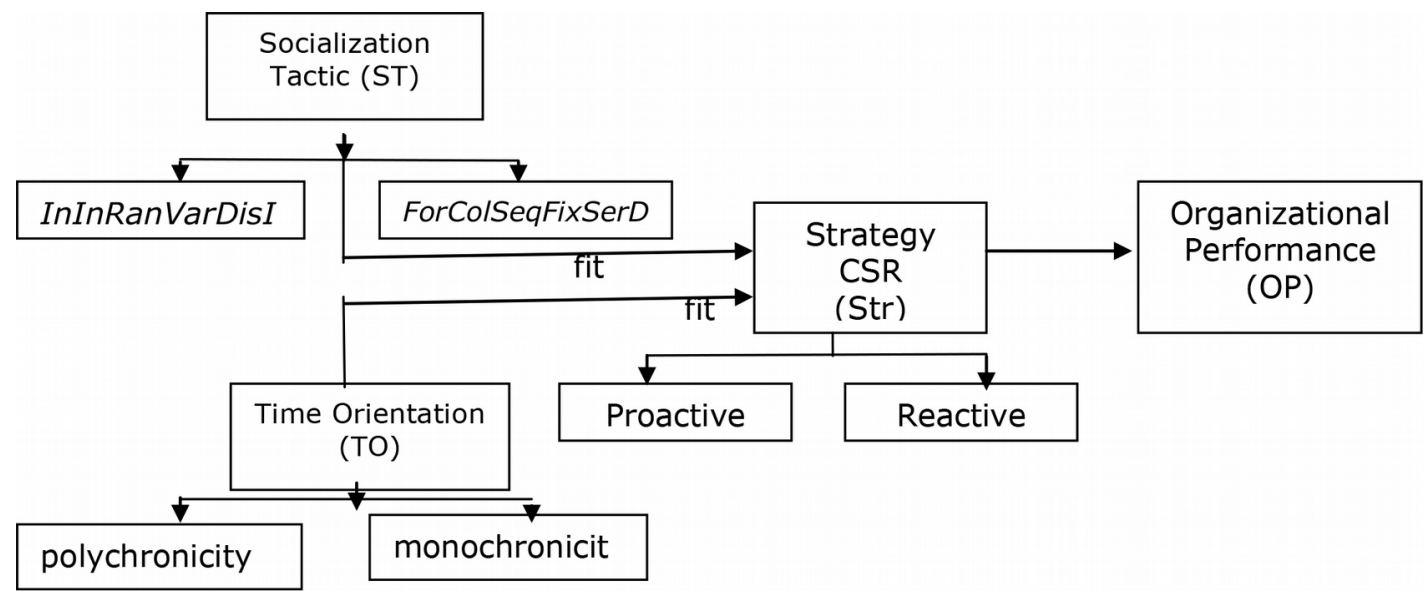

Figure 1. The Research Model

\section{Methodology}

This research used survey method. The samples were some CSR managers from state-owned companies in Indonesia. These managers have several employees to execute budget and CSR programs to society. Some of them have enough experience and some do not. CSR managers were given questionnaires from email or directly. The samples were limited to managers who have enough experience to gain new staff. Questionnaires were given to 250 managers. These questionnaires were returned and filled completely, amounted to 213 questionnaires. This means the response rate is $85 \%$. The concept of relationship fit used in this research was based on configuration and contingency perspective through euclidience distance measurement (Selto et al., 1995; Delery \& Doty, 1996; Muafi, 2009). In the process of analysis, datas were separated into two groups. First, managers from companies with proactive CSR strategy, and second is managers from companies with reactive CSR strategy. Highest mean value will be used to separate these managers. Variable were scaled using differential semantic scales from 1 to 7 except for organizational performance which used Likert scale from 1 to 7 . If the mean of CSR strategy variable from respondents are above 3.5, they will be used into proactive CSR strategy group. This separation is based from previous researches (Muafi, 2008, 2009; Robertson \& Chetty, 2000). This differential semantic scale is utilized to measure an object or a concept for respondents and it contains two contrary adjectives (Muafi, 2008, 2009; Hair, Anderson, Tatham \& Black, 1998). Validity and reliability test results show that every item has a significancy $\leq 0.05$ (valid) (Appendix A). However, in reliability examining points out Cronbach's alpha $\geq 0.6$ (reliable) (Appendix B). Statistical technique in this research is Linier regression with euclidience distance as well as Anova (analysis compare means one way Anova). Anova is used to understand the difference between two groups. Van de Ven and Drazin (1985), Selto et al. (1995), Muafi (2008, 2009, 2014), Priyono (2003, 2004), Riyanto (1999) and Delery and Doty (1996) suggest that the most appropriate in operationalization of configuration and contingency approaches is alignment system approach by looking for euclidience distance (ED). 


\subsection{Linier Regression with Euclidience Distance}

This research used system approach by testing the relationship fit by using deviation from design ideal type of contingency variable (socialization tactic and time orientation) that influences organizational performance. The model of linier regression with euclidience distance was done in two ways:

- contingency approach by using bivariate fit linier regression

- configuration approach by using multivariate fit linier regression

The independent variable is the relationship fit between CSR strategy with socialization tactic and time orientation. The dependent variable is organizational performance. Hypotheses are tested through simple linier regression coefficient with simple linier regression equation. Negatives and significant number from regression coefficient will be determined. The bigger the score of euclidience distance, it means the fit between variables is smaller (the distance between variable is closer), meaning that it will negatively influence organizational performance. On the other hand, the smaller the score of euclidience distance, it means the fit between variables is smaller, meaning that it will positively influence organizational performance (Muafi, 2014).

\section{Results}

\subsection{Regression Analysis for CSR Strategy (Proactive and Reactive)}

Regression euclidean distance (ED) analysis was used to test $\mathrm{H} 1, \mathrm{H} 2$ and $\mathrm{H} 3$ for CSR strategy groups (proactive and reactive). The result can be seen in Table 5 and it shows that $\mathrm{H} 1, \mathrm{H} 2$ and $\mathrm{H} 3$ are accepted. This is because CSR strategy (proactive and reactive) has resulted to negative and significant regression coefficient for all equation models.

\begin{tabular}{|c|c|c|c|c|}
\hline Regression equation model & Constanta & Coeficient (beta) & $\mathbf{t}$ & Sign \\
\hline $\mathrm{H} 1 . \mathrm{Y}=\mathrm{a}+\mathrm{b} 1$ dist (ST.Str) $+\mathrm{e}$ & 4.946 & -0.467 & -7.660 & $0.000 *$ \\
\hline H2. $Y=a+b 1$ dist (TO.Str) $+e$ & $£ 4.88$ & -0.435 & -7.010 & $0.000 *$ \\
\hline H3. $Y=a+b 1$ dist (ST.TO.Str) $+e$ & 5.985 & -0.550 & -9.535 & $0.000 *$ \\
\hline
\end{tabular}

*Significance at the $5 \%$ level

Table 5. The result of Hypothesis Testing Proactive and Reactive Strategy $(n=213)$

Next, before doing regression analysis for proactive CSR strategy group (Code 1 ) and reactive CSR strategy group (Code 2), ANOVA test was done with significancy of 0.00 . Because there is a difference for strategy, analysis then continued for each proactive and reactive strategy groups. 


\subsection{Proactive CSR Strategy Group ( $n=110$ with Code 1$)$}

Table 6 shows the result from proactive strategy group. In the contingency approach, there is fit between proactive strategy with InInRanVasDisIn socialization tactic as well as fit between proactive strategies with polychronicity time orientation. In the configuration approach, there is fit between proactive strategies with InInRanVasDisIn socialization tactic and polychronicity time orientation, meaning $\mathrm{H} 1 \mathrm{a}, \mathrm{H} 2 \mathrm{a}$, and $\mathrm{H} 3 \mathrm{a}$ is accepted. This is because proactive CSR strategy has resulted to negative and significant regression coefficient for all equation models.

\begin{tabular}{|c|c|c|c|c|}
\hline Regression equation model & Constanta & Coeficient (beta) & $\mathbf{t}$ & Sign \\
\hline $\mathrm{H} 1 \mathrm{a} . \mathrm{Y}=\mathrm{a}+\mathrm{b} 1$ dist (ST.Str) $+\mathrm{e}$ & 5.208 & -0.481 & -5.695 & $0.000 *$ \\
\hline H2a. $Y=a+b 1$ dist (TO.Str) $+e$ & 5.182 & -0.459 & -5.364 & $0.000 *$ \\
\hline H3a. $Y=a+b 1$ dist (ST.TO.Str) $+e$ & 5.718 & -0.438 & -5.063 & $0.000 *$ \\
\hline
\end{tabular}

*Significance at the $5 \%$ level

Table 6. The result of Hypothesis Testing Proactive Strategy $(n=110)$

\subsection{Reactive CSR Strategy Group ( $n=103$ with Code 2)}

On Table 7, there is fit between reactive strategies with ForColSeqFixSerDiv socialization tactic. The same thing also happens between reactive strategies with monochronicity time orientation. Configuration approach, there is fit between reactive strategies with ForColSeqFixSerDiv socialization tactic and monochronicity time orientation. This explanation has accepted $\mathrm{H} 1 \mathrm{~b}$, $\mathrm{H} 2 \mathrm{~b}$ and $\mathrm{H} 3 \mathrm{~b}$. This is because reactive CSR strategy has resulted to negative and significant regression coefficient for all equation models.

\begin{tabular}{|l|r|r|r|r|}
\hline \multicolumn{1}{|c|}{ Regression equation model } & \multicolumn{1}{c|}{ Constanta } & Coeficient (beta) & \multicolumn{1}{c|}{ Sign } \\
\hline H1.b. $\mathrm{Y}=\mathrm{a}+\mathrm{b} 1$ dist (ST.Str) $+\mathrm{e}$ & 4.418 & -0.530 & -6.283 & $0.000^{*}$ \\
\hline H2.b. $\mathrm{Y}=\mathrm{a}+\mathrm{b} 1$ dist (TO.Str)+e & 4.299 & -0.486 & -5.586 & $0.000^{*}$ \\
\hline H3.b. $\mathrm{Y}=\mathrm{a}+\mathrm{b} 1$ dist (ST.TO.Str)+e & 5.002 & -0.482 & -5.522 & $0.000^{*}$ \\
\hline
\end{tabular}

*Significance at the $5 \%$ level

Table 7. The result of Hypothesis Testing Reactive Strategy $(\mathrm{n}=103$ )

\section{Discussion}

To clarify the understanding on the influence of fit degree, there is a finding that overall CSR stategy has fit between socialization tactic and time orientation on CSR strategy at stateowned enterprises in Indonesia. This means it will increase their organizational performance, configuration and contingency approach. This finding is in line with Muafi (2009), stating that 
the success of a strategy is about vertical combination (external fit) and horizontal (internal fit). This condition is a combination from configuration of a system within an organization so it will complement each other. In configuration perspective, this concept tests both vertical and horizontal fit just as explained by Dyer and Reeves (1995) and Muafi (2009) that (1) bundles or configuration from human resource activity is important in increasing productivity of employees rather than single activity, and (2) able to control employees turnover and increase product quality so HR bundles need to be integrated with other business function practice (for example socialization tactic and time orientation) so that organizational performance will be increased even more. This is in line with Delaney and Husehild (1996), Bjorkman and Xiucheng (2002) and Muafi (2009). A finding shows that there is fit from two contingency variables which is socialization tactic and time orientation with CSR strategy that has been implemented. This will have an effect on organizational performance increase. It has been proven that business performance of state-owned enterprises in Indonesia is relatively increasing every year. This proves that this research is in line with Aragón-Correa (1998) concludes that companies with proactive business strategies should be using corrective approach and preventive natural environment approach. There is a relationship between business and society in seeing the importance of developing real eco-sustainability strategy. Olson, Iyer, Fielding and Zacher (2012) has recommended that managers need the support from all stakeholders in implementing pro environment attitude and behavior. CSR strategy is important for company success, which is organizational performance (Heslin \& Ochoa, 2008; Arx \& Ziegler, 2008). The implementation of strategy and CSR program is beneficial for building strong relationship with employees, society government and other stakeholders so it will increase their performance as well as their competitiveness continuously. CSR strategy should be integrated with company business strategy. Companies should also be focused on the best CSR communication to their stakeholders and CSR brand, too (McElhaney, 2009).

The result from analysis data shows that both contingency and configuration approach, both for proactive and reactive CSR strategy groups have fit of socialization tactic and time orientation. Contingency and configuration approach, there is fit between proactive CSR strategy with InInRanVarDisIn socialization tactic and polychronicity time orientation so organizational performance is expected to increase. On the other hand, contingency and configuration approach, there is fit between reactive CSR strategy with ForColSeqFixSerDiv and monochronicity time orientation.

In the contingency and configuration perspective, Edelman, Brush and Manolova (2005) and Muafi (2009) explained that company strategy needs to be fit with internal capability or company resources. Socialization program needs to be use to understand external challenge from the organization and to understand HRM policy in socialization to facilitate the achievement of company's strategic goals. Companies need to socialize institution and proactive behavior because it is connected to the studying process for new CSR agents, so it will help them in adapting and controlling process. There is an expectation for such agents to 
no longer face hardships when implementing CSR programs. Referring to the recommendation by Saeed et al. (2013) that organization should be not only aware and responsive to new proactive behavior but also consider interaction from institution and individual socialization tactic. Organization should give insiders training and socialization agents respond positively for these newcomers. This is important because it's beneficial in organizational performance achievement such as work quality, work satisfaction, organizational capability, work adaptability and service quality.

Robbins and Judge (2007) stated that the more different of new employees background with their new soon-to-be job and the further their new role with their previous role, the more formal socialization so that implemented CSR strategy should use reactive CSR strategy. There is a necessity of orientation program and specific training in going through socialization in groups, by using role model who train and give them spirit for newcomers, applying standard transitional stages, reducing certain characteristic from hired people and forming new employees to be ready for their new role. Related to time orientation, monochronicity person can only concentrate on one type of job, uncomfortable in doing many jobs at once, have a deadline, religious, focused and get used to short-term relationship.

On the other hand, polychronicity person likes formal socialization more. This means companies are ready to place new employees to their new job with little attention, doing socialization process all by themselves, role model are non-existent, transitional schedule is not given from the start because those who are ready for next stage aren't promoted for next stage. The most important matter is quality and newcomers' qualification as their main concern to increase organizational performance. Implemented CSR strategy should use proactive strategy. It needs to be considered that this proactive strategy will fit if it's applied on polychronicity employees which is: doing different jobs at once, heed on interruption, considering their objectives, more commitment on human relationship, care for their friends, colleagues and family as well as the tendency to have a long-term relationship (Robbins \& Judge, 2012). This is in line with Goonetilleke and Luximon (2010) who concluded that monochronicity individual in focused on respondents' attention in their tasks and achieving highest performance. For polychronicity individual, their total performance is more than one task under limited time. This indicated that time management of an individual should consider training and controlling to understand the difference between one another. It should be noted that several organizations prefer polychronicity to increase their competitive advantage (Love, 2009; Souitaris \& Maestro, 2010; Zhang, 2013). Polychronicity will be significant if it's connected to personality of extraversion, agreeableness and openness to experience. There is also a connection between multitasking ability and polychronic (Sanderson, 2012). 


\section{Research Contribution}

\subsection{Theoretical Contribution}

The finding of this research is developing theory on the importance of having fit between contingency variable with CSR strategy in increasing organizational performance (contingency and configuration approach). This research shows that in order to effectively implementing organization's strategies, especially CSR strategy, company needs to gain supports from the correct socialization tactic and time orientation. This is because if socialization tactic and time orientation is fit with CSR strategy, it will increase organizational performance even more. Future research should consider other contingency variable such as environment uncertainty, social responsible behavior, organizational structure, HR practice, and leadership style (Muafi, 2015a, 2015b). The need for consistency in strategies implementation and internal factors management in the organization is necessary to achieve a higher organizational performance (Muafi, 2015b).

Due to the object being limited to internal variables without considering the existence of time change and environment change, the research model concluded in this research is deemed as static model. Therefore, it is necessary to consider dynamic model which was introduced by Zajac, Kraat, and Bresser (2000) and others such as Nissen and Leweling (2008). Such model had considered two approaches with both static and dynamic characteristics

\subsection{Practical Contribution}

There is a necessity for consistency within companies in strategy implementation and contingency factor management to achieve better organizational performance. Fit between CSR strategy with the elements within organization fit theory. In organization fit theory framework especial in human resource management, there is a belief for doing ideal type of configuration and contingency approach for organizational performance. This condition is expected to be possessed by state-owned enterprises in Indonesia to make them having better organizational position compared to their competitors. It is also important to give understanding and training to identify the difference of strategy option because it will influence the difference of managers' perception on socialization tactic and time orientation.

Furthermore, management should pay more attention to strategic factors especially on the fit of strategic relationship with socialization tactic and time orientation in implementing CSR program to support organizational performance. A company should focus not only on strategic change but also on socialization tactic and time orientation. 


\subsection{Methodological Contribution}

In testing the fit of the relationship of contingency variable with organization's strategies, both contingency as well as configuration has been done by referring to the method of Van de Ven and Drazin (1985). Such method had also been done by various others such as Selto et al. (1995), Delery and Doty (1996) and several from Indonesia (Priyono, 2003, 2004; Riyanto, 1999; Muafi, 2008, 2009, 2014). In testing the fit of a relationship, both contingency and configuration are superior in terms of research method which used euclidience distance, and used multivariate fit and bivariat fit linier regression. This research model used system approach by testing the fit of a relationship, using deviation from design ideal type for socialization tactic and time orientation or contingency variable that influences organizational performance, hence it could be acknowledged the value of the influence between ideal relationship from CSR strategy, socialization tactic and time orientation. Van de Ven and Drazin (1985) recommended that eucledience distance is the best method to be used in system approach with big samples.

It is encouraged for future researches to combine both financial and non financial performance, (e) considering control variable in a research for example company's age, manager's age, educational level and the amount of employees as control variable proves that such control variable has no influence on performance compared to contingency variable, and ( $f$ ) considering dynamic model for future use by considering longitudinal type of research. These limitations can hopefully be used and managed for future researches to develop a better and perfect research model.

\section{References}

Ali, I., Rehman, K.U., Yilmaz, A.K., Nazir, S. \& Ali, J.F. (2010a). Effects of corporate social responsibility on consumer retention in cellular industry of Pakistan. African Journal of Business Management, 4(4), 475-485.

Ali, I., Rehman, K.U., Ali, S.I., Yousaf, J., \& Zia, M. (2010b). Corporate social responsibility influences, employee commitment and organizational performance. African Journal of Business Management, 4(12), 2796-2801.

Allen, D.G. (2006), Do Organizational Socialization Tactics Influence Newcomer Embeddedness and Turnover?. Journal of Management, 32, 237-256. http://dx.doi.org/10.1177/0149206305280103

Alleyne, P., Doherty, L., \& Greenidge, D. (2005). Human resource management and performance in the Barbados Hotel Industry. International Journal of Hospitality Management, 25(4), 623-646. http://dx.doi.org/10.1016/j.ijhm.2005.05.001 
Aragón-Correa, J.A., \& Rubio-López, E.A. (2007). Proactive Corporate Environmental Strategies: Myths and Misunderstandings. Long Range Planning, 40, 357-381.

http://dx.doi.org/10.1016/j.Irp.2007.02.008

Aragón-Correa, J.A. (1998). Strategic proactivity and firm approach to the natural environment. Academy of Management Journal, 41(5), 556-567. http://dx.doi.org/10.2307/256942

Armstrong, M. (2008). Strategic Human resource Management. A Guide To Action. $4^{\text {th }}$ edition. London and Philadelphia, Typeset by Saxon Graphics Ltd, Derby Printed and bound in India by Replika Press Pvt Ltd.

Arx, U.V., \& Ziegler A. (2008). The effects of CSR on stock performance: new evidence for USA and Europe. Economic Working Paper Series. Swiss Federal Institute of Technology Zurich.

Ashforth, B.E., Sluss, D.M., \& Saks, A.M. (2007). Socialization tactics, proactive behavior, and newcomer learning: Integrating socialization models. Journal of Vocational Behavior, 70, 447-462. http://dx.doi.org/10.1016/j.jvb.2007.02.001

Baker III, H.E., \& Feldman, D.C. (1991). Linking Organization Socialization Tactics With Corporate Human Resource Management Strategies. Human Resource Management Review, 1(3), 193-202. http://dx.doi.org/10.1016/1053-4822(91)90014-4

Bates, W. (1992). Aligning information systems with business strategy. Journal of Strategic Information Systems, I(4), 205-213. http://dx.doi.org/10.1016/0963-8687(92)90036-V

Berry, M.A., \& Rondinelli, D.A. (1998). Proactive Corporate Environment Management: A New Industrial Revolution. Academy of Management Executive, 12(2), 38-50.

Björkman, I., \& Xiucheng, F. (2002). HRM and the performance of Western firms in China. International of HRM, 13, September, 853-864.

Brammer, S., Millington, A., \& Rayton, B. (2007). The contribution of corporation social responsibility to organizational commitment. International Journal Human Resources Management, 18(10), 1701-1719. http://dx.doi.org/10.1080/09585190701570866

Chen, J., \& Eldridge, D. (2010). Organizational Socialization Tactics and newcomer adjustment in the Chinese context: Perceived organizational support as mediator. Working Paper Series, No. 1. Centre for Organisations in Development, Institute for Development Policy and Management, School of environment and Development, The University of Manchester, Arthur Lewis Building Manchester. Available online at: http://www.manchester.ac.uk/cod

Choe, J-M. (2003). The effect of environmental uncertainty and strategic application of IS on a firm's performance. Information and Management, 40(4), 257-268. 
D'Amat, A., Henderson, S., \& Florence, S. (2009). Corporate Social Responsibility And Sustainable Business. A Guide to Leadership Tasks and Functions. Center for Creative Leadership Greensboro, North Carolina. Published by CCL Press.

David, F.R. (2009). Strategic management: Concepts and Cases. Upper Saddle River, NJ: Pearson Prentice Hall.

Delaney, J.T., \& Husehild, M.A. (1996). The Impact of Human Resources Management Practices on Perceptions of Organizational Performance. Academic of Management Journal, 39(4), 949-969. http://dx.doi.org/10.2307/256718

Delery, J.E., \& Doty, D.H. (1996). Modes of Theorizing in Strategic Human Resource Management: Tests of Universalistic, Contingency, and Configurational Performance Predictions. The Academy of Management Journal, 39(4), 802-835.

http://dx.doi.org/10.2307/256713

Dyer, L., \& Reeves, T. (1995). Human resources strategies and firm performance: what do we know and where do we need to go? The International Journal of Human Resources Management, 6, 656-670. http://dx.doi.org/10.1080/09585199500000041

Edelman, L.F., Brush, C.G., \& Manolova, T. (2005). Co-alignment in the resource-performance relationship: strategy a mediator. Journal of Business Venturing, 20, 359-383. http://dx.doi.org/10.1016/j.jbusvent.2004.01.004

Elbanna, S., \& Alhwarai, M. (2012). The Influence Of Environmental Uncertainty And Hostility On Organization Performance. Working paper series. Faculty of Business and Economics, UAEU.

Fang, S.R., Huang, C.Y., \& Huang, S.W.L. (2010). Corporate social responsibility strategies, dynamic capability and organizational performance: Cases of top Taiwan-selected benchmark enterprises. African Journal of Business Management, 4(1), 120-132.

Gomez, C. (2004). The influence of environmental, organizational, and HRM factors on employee behaviors in subsidiaries: A Mexican case study of organizational learning. Journal of World Business, 39, 1-11. http://dx.doi.org/10.1016/j.jwb.2003.08.006

Goonetilleke, R.S., \& Luximon, Y. (2010). The Relationship between monocronicity and polychronicity and individual characteristics. Behaviour \& Information Technology, 29(2), 187-198. http://dx.doi.org/10.1080/01449290903222697

Gruman, J.A., Saks, A.M., \& Zweig, D.I. (2006). Organizational socialization tactics and newcomer proactive behaviors: an integrative study. Journal of Vocational Behavior, 69, 90-104. http://dx.doi.org/10.1016/j.jvb.2006.03.001 
Hair, J.F., Anderson, R.E., Tatham, R.L., \& Black, W.C. (1998). Multivariate Data Analysis. Englewood Cliffs, NJ: Prentice-Hall International.

Harel, G.H., \& Tzafrir, S.S. (1999). The Effect of Human Resource Management Practices On The Perception Of Organizational and Market Performance Of The Firm. Human Resources Management, Fall, 38(3), 185-200. http://dx.doi.org/10.1002/(SICI)1099-050X(199923)38:3<185::AIDHRM2>3.0.CO;2-Y

Hendriques, I., \& Sadorsky, P. (1996). The determinants of an environmentally responsive firm: An empirical approach. Journal of Environmental Economics and Management, 30, 381-395. http://dx.doi.org/10.1006/jeem.1996.0026

Hendriques, I., \& Sadorsky, P. (1999). The Relationship Between Environmental Commitment and Managerial Perceptions of Stakeholders Importance. Academy of Management Journal, 42, 87-99. http://dx.doi.org/10.2307/256876

Heslin, P.A., \& Ochoa, J.D. (2008). Understanding and Developing Strategic Corporate Social Responsibility. Organizational Dynamics, 37, 125-144. http://dx.doi.org/10.1016/j.orgdyn.2008.02.002

Hickman, C.R., \& Silva, M.A. (1984). Creating Excellent. The New American Library of Canada Ltd.

Homburg, C., Krohmer, H., \& Workman Jr, J.P. (1999). Strategic Consensus and Performance: The Role of Strategy Type and Market-Related Dynamism. Strategic Management Journal, 20, 339-357. http://dx.doi.org/10.1002/(SICI)1097-0266(199904)20:4<339::AID-SMJ29>3.0.CO;2-T

Jones, G.R. (1986) Socialization tactics, self efficacy, and newcomers' adjustments to organizations. Academy of Management Journal, 29, 262-279. http://dx.doi.org/10.2307/256188

Kaufman-Scarborough, C. (2003). Two Perspectives on the Tyranny of Time: Polychronicity and Monochronicity as Depicted in Cast Away. The Journal of American Culture, 26(1), 87-95. http://dx.doi.org/10.1111/1542-734X.00076

Kaufman-Scarborough, C., \& Lindquist, J.D. (1999). Time management and polychronicity: Comparisons, contrasts, and insights for the workplace. Journal of Managerial Psychology, 14(3/4), 288-312. http://dx.doi.org/10.1108/02683949910263819

Kempt, M. (2001). Corporate Social Responsibility in Indonesia, Quixotic Dream or Confident Expectation? Programe Paper Number, November, Technology, Business and Society, United Nations Research Institute for Social Development. 1-41.

Konig, C.J., \& Waller, M.J. (2010). Time for Reflection: A Critical Examination of Polychronicity. Human Performance, 23, 173-190. http://dx.doi.org/10.1080/08959281003621703 
Kotter, J.P., \& Heskett, J.L. (1992). Corporate Culture and Performance. New York: The Free Press, Macmillan International.

Kreitner, R., \& Kinicki, A. (2007). Organizational Behavior. 7th ed. New York: McGraw Hill.

Kumar, K., Subramanian, R., \& Yauger, C. (1997). Pure versus Hybrid: Performance Implications of Porter's generic Strategies. Health care Management, Fall, 47-60. http://dx.doi.org/10.1097/00004010-199710000-00008

Lee, M.D.P. (2008). A review of the theories of corporate social responsibility: Its evolutionary path and the road ahead. International Journal of Management Review, 10(1), 53-73. http://dx.doi.org/10.1111/j.1468-2370.2007.00226.x

Lindquist, J.D., \& Kaufman-Scarborough, C.J. (2007). The Polychronic-Monochronic Tendency Model PMTS scale development and validation. Time \& Society, 16(2/3), 269-301. http://dx.doi.org/10.1177/0961463×07080270

Love, L.M. (2009). Impacts of Imposed Polychronics behaviour upon performance and well being in academic work environments. Tesis. Magister Management, Massey University, Turitea, Palmerstone North, New Zealand.

Lukas, B.A., Tan, J.J., \& Hult, G.T.M. (2001). Strategi fit in transitional economies: The case China's electronics industry. Journal of Management, 27(4), 409-429.

http://dx.doi.org/10.1177/014920630102700402

Luo, Y. (1999). Environment Strategy Performance Relation in Small Business in China: A Case of Township and Village Enterprise in Southern China. Journal of Small Business Management, January, 37-52.

McElhaney, K. (2009). A Strategic Approach to Corporate Social Responsibility. Leader to Leader, Executive Forum, 52, 30-36. http://dx.doi.org/10.1002/ttl.327

McGahan, A.M., \& Mitchell, W. (2003), How do firm change in the face of constraints to change? Towards an agenda for research in strategic organization. Strategic Organization 1(2), 231-239. http://dx.doi.org/10.1177/1476127003001002308

Muafi (2008). Integration, Configuration and Contingency Model; Environment-StrategyPerformance. Dissertation. Brawijaya University.

Muafi (2009). The effects of alignment competitive strategy, culture, and role behavior on organizational performance in service firms. The International Journal of Organizational Innovation, 2(1), 106-134. 
Muafi. (2014). From HR Strategi to HR Performance. Jurnal Keuangan dan Perbankan, 18(3, September), 475-488.

Muafi. (2015a). Antecedent Counterproductive Behavior: SMEs Cases. Polish Journal of Management Studies, 12(2), 114-121.

Muafi. (2015b). Green IT empowerment, social capital, creativity and innovation: A case study of creative city, Bantul, Yogyakarta, Indonesia. Journal of Industrial Engineering and Management, 8(3), 719-737.

Nissen, M.A., \& Leweling, T.A. (2008). Conceptualizing dynamic organizational fit in Multicontingency contexts. Proceedings Academy of Management Conference, Anaheim, CA. $1-38$.

Oliver, C., \& Holzinger, I. (2008). The effectiveness of strategic political management: a dynamic capabilities framework. Academy of Management Review, 33(2), 496-520. http://dx.doi.org/10.5465/AMR.2008.31193538

Olson, M.J.B., Iyer, A., Fielding, K.S., \& Zacher, H. (2012). Relationship between Daily Affect and Pro-Environmental Behavior at Work; The Moderating Role of Pro- Environmental Attitudes. Journal of Organizational Behavior, 1-42.

Onken, M.H. (1999). Temporal elements of organizational culture and impact on firm performance. Journal of Managerial Psychology, 14(3/4), 231-244.

http://dx.doi.org/10.1108/02683949910263756

Palmer, D.K., \& Schoorman, F.D. (1999). Unpackaging the multiple aspects of time in polychronicity. Journal of Managerial Psychology, 14, 323-345.

http://dx.doi.org/10.1108/02683949910263918

Priyono, B.S. (2003). Pengaruh Praktik SDM sebagai faktor Kontingensi Strategi terhadap Kinerja. Jurnal Bisnis dan Ekonomi, 10(2), 209-235.

Priyono, B.S. (2004), Pengaruh Derajat Kesesuaian Hubungan Strategi, Struktur, Sistem Karir dan Budaya Organisasi Terhadap Kinerja. Disertasi. UGM.

Rahim, R.A., Jalaludin, F.W., \& Tajuddin, K. (2011), The Importance Of Corporate Social Responsibility On Consumer Behaviour In Malaysia. Asian Academy of Management Journal, 16(1), 119-139.

Riyanto, B. (1999). The effect of attitude, strategy and decentralization on the effectiveness of budget participation. Journal Riset Akuntansi Indonesia, 2(2), 136-153. 
Robbins, S.P. \& Judge, T.A. (2007). Organizational Behaviour (12th ed.). New Jersey: Prentice-Hall.

Robbins, S.P., \& Judge, T.A. (2012). Organizational Behavior. Upper Saddle River, New Jersey: Pearson Education, Inc.

Robertson, C., \& Chetty, S.K. (2000). A Contingency based approach to understanding export performance. International Business Review, 9, 211-235.

http://dx.doi.org/10.1016/S0969-5931(99)00037-2

Rodopman, O.B. (2009). The role of proactivity during organizational entry: Proactive socialization tactics, citizenship and counterproductive work behaviors. Graduate School Theses and Dissertations. Ozgun Burcu Rodopman. http://scholarcommons.usf.edu/etd/2170

Saeed, M., Shamsodin, N., \& AhmadReza, K.M. (2013). How Institutional Socialization Tactics Affects the Drivers of Socialization, Newcomers' Proactivity and Socialization Outcomes. Research Journal of Recent Sciences, 2(6), 11-16.

Saks, A.M., Uggerslev, K.L., \& Fassina, N.E. (2007). Socialization tactics and newcomer adjustment: A meta-analytic review and test of a model. Journal of Vocational Behavior, 70, 413-446. http://dx.doi.org/10.1016/j.jvb.2006.12.004

Sanderson, K.R. (2012), Time Orientation in Organizations: Polychronicity and Multitasking. FIU Electronic Theses and Dissertations. Paper 738. Available online at: http://digitalcommons.fiu.edu/etd/738

Schriber, J.B. \& Gutek, B.A. (1987). Some time dimensions of work: Measurement of an underlying aspect of organization culture. Journal of Applied Psychology, 72, 642-650. http://dx.doi.org/10.1037/0021-9010.72.4.642

Schuler, R.S., \& Jackson, S.E. (1987). Linking competitive strategy with Human Resources Management Practices, Academic of Management Executive, I(3), 207-219. http://dx.doi.org/10.5465/AME.1987.4275740

Selto, F.H., Renner, C.J., \& Young, S.M. (1995). Assessing The Organizational Fit Of A Just In Time Manufacturing System; Testing Selection, Interaction and System Models Of Contingency Theory. Accounting Organizations and Society, 20(7/8), 665-684. http://dx.doi.org/10.1016/0361-3682(95)00022-2

Shane, S., \& Kolvereid, L. (1995). National Environment, Strategy, and New Venture Performance; A Three Country Study. Journal of Small Business Management, 37-50. 
Souitaris, V., \& Maestro, B.M.M. (2010). Polychronicity in top management teams: The impact on strategic decision processes and performance of new technology ventures. Strategic Management Journal, 31(6), 652-678.

Suparyono, W. (2012). Funds Allocation Mapping and Corporate Social Responsibility Program (Program Kemitraan Dan Bina Lingkungan-PKBL): Case in Indonesia. Global Journal of Management and Business Research, 12(7), 53-65.

Suprapto, B. (2006). The Implication of Fit between Natural Environmental Approach and Business Strategy on Performance. Proceedings of the 1st International Conference on Natural Resources Engineering \& Technology. Putrajaya, Malaysia. 346-358.

Takeuchi, N., \& Takeuchi, T. (2009). A longitudinal investigation on the factors affecting newcomers' adjustment: Evidence from Japanese organizations. International Journal of Human Resource Management, 20, 928-952. http://dx.doi.org/10.1080/09585190902770877

Taleghani, N., Delafrouz, N., \& Tonekaboni, S.M.S. (2012). Investigation of Corporate Social Responsibility's Effect on Industrial Brand Performance in Industrial Markets. Journal of Basic and Applied Scientific Research, 10598-10606.

Torugsa, N., O'Donohue, W., \& Hecker, R. (2012). Capabilities, Proactive CSR and Financial Performance in SMEs: Empirical Evidence from an Australian Manufacturing Industry Sector. Journal of Business Ethics, 109(4), 483-499. http://dx.doi.org/10.1007/s10551-011-1141-1

Twomey, D.F., \& Harris, D.L. (2000), From Strategy to Corporate Outcomes: Aligning Human Resources Management System with Entrepreneurial Intent. International Journal Of Commerce and Management, 10, 43-55. http://dx.doi.org/10.1108/eb047408

Uriarte, F.A. (2008). Corporate Social Responsibility in ASEAN. LCF CSR Conference, Manila, Philippines.

Van de Ven, A.H., \& Drazin, R. (1985). The Concept of Fit in Contingency Theory. Research in Organizational Behavior, 7, 333-365.

Van Maanen, J., \& Schein, E.H. (1979). Toward a theory of organizational socialization, Research in Organizational Behavior, 1, 209-264.

Wartick, S.L., \& Cochran, P.L. (1985). The Evaluation of the Corporate Social Performance Model. Academy of Management Review, 10(4), 758-769.

Whipp, R., Adam, B., \& Sabelis, I. (2002). Making Time: Time and Management Modern Organisations. US: Oxford University Press. 
Wood, D.J. (1991). Corporate social performance revisited. Academy of Management Review, 16(4), 691-718.

Zajac, E.J., Kraatz, M.S., \& Bresser, R.K.F. (2000). Modeling the dynamics of strategic fit: A normative approach to strategic change. Strategic Management Journal, 21(4), 429-453. http://dx.doi.org/10.1002/(SICI)1097-0266(200004)21:4<429: :AID-SMJ81>3.0.CO;2-\#

Zhang, W. (2013). The Influence Of Polychronic Time Use On Job Satisfaction, Work Engagement, And Turnover Intention: A Study Of Non-Supervisory Restaurant Employees. Thesis. Master of Science, Kansas State University, Manhattan Kansas.

Zwaan, L. (2006). Assessing Organizational Culture in a Private Hospital in the Western Cape Leigh Zwaan, Thesis, Department of Industrial Psychology, Faculty of Economic and Management Science, University of the Western Cape.

\section{Appendix A. Correlation between multiple and single measure}

\begin{tabular}{|l|r|r|}
\cline { 2 - 3 } \multicolumn{1}{c|}{} & Pearson correlation & \multicolumn{1}{c|}{ Sign } \\
\hline Socialization Tactics (6 items) & $0.442 *$ & 0.000 \\
& $0.445 *$ & 0.001 \\
& $0.542^{*}$ & 0.000 \\
& $0.352^{*}$ & 0.000 \\
& $0.343 *$ & 0.002 \\
& $0.510 *$ & 0.000 \\
\hline Time Orientation (10 items) & $0.342 *$ & 0.000 \\
& $0.414 *$ & 0.000 \\
& $0.313 *$ & 0.000 \\
& $0.322^{*}$ & 0.002 \\
& $0.443 *$ & 0.001 \\
& $0.310 *$ & 0.000 \\
& $0.422^{*}$ & 0.003 \\
& $0.343 *$ & 0.001 \\
& $0.510 *$ & 0.000 \\
& $0.431 *$ & 0.000 \\
\hline Organizational Performance(5 items) & $0.422 *$ & 0.000 \\
& $0.343 *$ & 0.001 \\
& $0.320 *$ & 0.000 \\
& $0.452 *$ & 0.003 \\
& $0.373 *$ & 0.001 \\
& $0.590^{*}$ & 0.000 \\
\hline 6 items) & $0.411 *$ & 0.000 \\
& $0.420 *$ & 0.000 \\
& $0.352^{*}$ & 0.003 \\
& $0.473 *$ & 0.002 \\
& $0.490 *$ & 0.000 \\
\hline
\end{tabular}




\section{Appendix B. Scale Reliability}

\begin{tabular}{|l|r|}
\cline { 2 - 2 } \multicolumn{1}{c|}{} & \multicolumn{2}{c|}{ Standardized Alpha } \\
\hline Socialisation Tactis & 0.634 \\
\hline Time Orientation & 0.664 \\
\hline CSR Strategy & 0.720 \\
\hline Organizational Performance & 0.810 \\
\hline
\end{tabular}

Journal of Industrial Engineering and Management, 2016 (www.jiem.org)

Article's contents are provided on an Attribution-Non Commercial 3.0 Creative commons license. Readers are allowed to copy, distribute and communicate article's contents, provided the author's and Journal of Industrial Engineering and Management's names are included. It must not be used for commercial purposes. To see the complete license contents, please visit http://creativecommons.org/licenses/by-nc/3.0/. 